\title{
Repeatability of morpho-agronomic characters of Theobroma grandiflorum fruits
}

\author{
Ayulle Thalía Watson Alcoforado ${ }^{1}$, Cássia Ângela Pedrozo ${ }^{2}$, \\ Marcos Miguel Mayer ${ }^{1}$, Hyanameyka Evangelista de Lima-Primo³
}

\begin{abstract}
The objective of this study was to estimate coefficients of repeatability, to determine the minimum number of fruits necessary for genotype selection and to estimate phenotypic correlation coefficients between morpho-agronomic characters of Theobroma grandiflorum fruits. It was evaluated twenty - two genotypes of an agroforestry system implanted in the municipality of Cantá - RR. Ten fruits per genotype were collected and evaluated for longitudinal length, transverse diameter, total weight, peel thickness, peel weight, pulp weight, placental weight and wet seed weight. Four statistical methods were used to estimate the repeatability coefficients: variance analysis, main components based on the correlation matrix and the covariance matrix, and structural analysis based on the correlation matrix. The number of measurements needed to predict the real value of the genotypes and the Pearson correlation coefficients among the characters were also estimated. The repeatability coefficients ranged from low to moderate, with 10 fruits per plant generally required, with $85 \%$ of confidence, in order to make an effective selection for most of the characters studied. There are possibilities of indirect gains for fruits with greater amount of pulp through the selection of larger and / or heavier fruits.
\end{abstract}

Index terms: genetic variability, selection of genotypes, phenotypic correlation.

\section{Repetibilidade de caracteres morfoagronômicos de frutos de cupuaçuzeiros}

Corresponding author: ayullethalia_ml@hotmail.com

Received: November 05, 2018 Accepted: January 18, 2019

Copyright: All the contents of this journal, except where otherwise noted, is licensed under a Creative Commons Attribution License.

\section{(cc) $\mathbf{E Y}$}

\begin{abstract}
Resumo - Este trabalho teve como objetivos estimar coeficientes de repetibilidade, determinar o número mínimo de frutos necessários para seleção de genótipos e estimar coeficientes de correlação fenotípica entre caracteres morfoagronômicos de frutos de cupuaçuzeiros. Foram avaliados 22 genótipos de um sistema agroflorestal implantado no município de Cantá - RR. Foram coletados 10 frutos por genótipo, os quais foram avaliados quanto ao comprimento longitudinal, ao diâmetro transversal, ao peso total, à espessura da casca e ao peso da casca, da polpa, da placenta e de sementes úmidas. Foram utilizados quatro métodos estatísticos para estimar os coeficientes de repetibilidade: análise de variância; componentes principais com base na matriz de correlações e na matriz de covariâncias, e análise estrutural com base na matriz de correlações. O número de medições necessárias para predizer o valor real dos genótipos e os coeficientes de correlação de Pearson entre os caracteres foi também estimado. Os coeficientes de repetibilidade variaram de baixo a moderado, sendo no geral necessários 10 frutos por planta, considerando $85 \%$ de confiança, para que seja realizada uma seleção efetiva para a maioria dos caracteres estudados. Há possibilidades de ganhos indiretos para frutos com maior quantidade de polpa por meio da seleção de frutos maiores e/ou mais pesados.
\end{abstract}

Termos para Indexação: variabilidade genética, seleção de genótipos, correlação fenotípica.

\footnotetext{
${ }^{1}$ Bachelor's Degree Student in Biological Sciences, Federal Institute of Education, Science and Technology of Roraima. Boa Vista - RR, Brazil. E -mail: ayullethalia_ml@hotmail.com(ORCID 0000-0002-4283-7517); marcosmyguelmayer@gmail.com (ORCID 0000-0002-4842-1846)

${ }^{2}$ Agricultural Engineer, D.Sc. Researcher, Brazilian Agricultural Research Corporation, Agroforestry Research Center of Roraima. Boa Vista - RR, Brazil. E-mail: cassia.pedrozo@embrapa.br (ORCID 0000-0002-0474-263x)

${ }^{3}$ Agricultural Engineer, D.Sc. Researcher, Brazilian Agricultural Research Corporation, Agroforestry Research Center of Roraima, Boa Vista - RR, Brazil. E-mail: hyanameyka.lima@embrapa.br ${ }^{\text {(ORCID 0000-0002-0595-5039) }}$
} 


\section{Introduction}

The cupuassu [Theobroma grandiflorum (Willd. ex Spreng.) K. Schum] is a fruit tree native to the Amazon region, whose pulp is rich in vitamins and minerals, and is much appreciated for the production of juices, biscuits, liqueurs, sweets and yogurts, among other foods (SOUZA et al., 1996; GONDIM et al., 2001; YANG et al., 2003). In addition, the seeds of the species are used in the manufacture of cosmetic products and "cupulate", a product similar to chocolate.

The cupuassu tree is cultivated in all states of the North region of the Brazil, justifying the conduction of breeding programs to develop varieties that provide competitive costs and good profitability for the entrepreneurs (ALVES, 2003). In addition to the characters such as quality and resistance to the main pests and diseases, the selection of genotypes that present fruits of larger size and with a higher percentage of pulp is desirable for the improvement of the species.

In breeding programs of perennial species, which require long periods of time for evaluation and selection of genotypes, methods capable of increasing the process efficiency should be prioritized. Among these methods is mentioned the repeatability coefficient, which can be estimated when the measurement of a given character is repeated, in time or space, in the same individual. The parameter measures the proportion of the total variance that is explained by the genetic effects and by the effects of the permanent environment, attributed to the common environment (CRUZ et al., 2004).

The number of measurements that must be made in each genotype so that the selection between genotype can be done efficiently, could be obtained by estimating the repeatability coefficients (CRUZ et al., 2004). It seeks to determine the minimum number of measurements necessary for the evaluation of genotypes, so that the evaluation of a number beyond the necessary implies an increase in time and labor, while the evaluation of a smaller number of measurements may reduce the efficiency of the selection of promising genotypes.

For the cupuassu tree, estimates of repeatability coefficients aiming to define the minimum number of fruits for evaluation and selection of promising genotypes were performed by Fonseca et al. (1990) and Costa et al. (1997), in plants of Amazonas and Acre, respectively. The repeatability estimates found by these authors ranged from low to moderate, indicating that, generally, with a determination coefficient of $80 \%$, it is necessary to evaluate from one to eigth fruits for selection purposes. However, the sampling used in these studies was very small, it was evaluated only three fruits and two fruits per genotype, respectively, which may reduce the accuracy of the estimates obtained in these studies.

The objective of this study was to estimate repeatability coefficients, to determine the minimum number of fruits required for genotype selection and to estimate phenotypic correlation coefficients among morpho-agronomic characters of cupuassu fruits.

\section{Material and Methods}

In the 2016/2017 harvest, mature fruits of 22 cupuassu tree genotypes, belonging to an agroforestry system implanted in 1995 in Confiança Experimental Field of Embrapa Roraima, located in the municipality of Cantá / RR, were evaluated. As component species of the agroforestry system are: Brazil nut (Bertholletia excelsa), "cupiúba" (Goupia glabra), cupuassu; coffee (Coffea canephora); "saman" (Samanea saman); "abiu" (Micropholis venulosa); "andiroba" (Carapa guianensis) and "gliricidia" (Gliricidia sepium), the last one being present in the boundary. The region presents forest vegetation, Ami type climate (Köppen), and precipitation varying between $1795-2385 \mathrm{~mm}_{\text {year }}{ }^{-1}$, with rainy season concentrated in the months of May to July, which corresponds to more than $55 \%$ of the total precipitation.

The fruits were randomly collected and transported to the Embrapa Roraima Post Harvest Laboratory for evaluation of the following characters: longitudinal length $(\mathrm{LL} ; \mathrm{cm})$, transverse diameter (TD; cm), total weight (TW, $\mathrm{g}$ ), peel thickness (PT; cm), peel weight (PW; g), pulp weight (PPW; g), placental weight (PLP; g) and wet seed weight (WSW; g). The characters related to weight were evaluated using analytical balances, while those related to the diameter were measured with a digital caliper.

The repeatability coefficients were estimated by four different methods (CRUZ et al., 2004):

- Analysis of variance (ANOVA): by this method, to estimate the repeatability coefficients, we initially perform analysis of variance for all the characters, adopting the following model:

$\mathrm{Y}_{\mathrm{ij}}=\mu+\mathrm{g}_{\mathrm{i}}+\varepsilon_{\mathrm{ij}} \quad$ where: $\mathrm{Y}_{\mathrm{ij}}$ is the observation regarding the $\mathrm{i}$-th genotype in the $\mathrm{j}$-th fruit; $\mu$ is the overall average; $g_{i}$ is the random effect of the $i$-th genotype under the influence of the permanent environment $(i=$ $1,2, \ldots, 22)$; and $\varepsilon_{\mathrm{ij}}$ is the experimental error associated with observation $\mathrm{Y}_{\mathrm{ij}}$.

After the analysis of variance, the coefficient of repeatability (r) is calculated by the following expression:

$$
r=\frac{\widehat{\sigma}_{y}^{2}}{\widetilde{\sigma}^{2}+\tilde{\sigma}_{g}^{2}}
$$

where: $\hat{\sigma}_{g}^{2}$ is the estimation of the variance among the genotypes and $\hat{\sigma}$ is the estimate of the variance of the experimental error, obtained by means of the mean squares of the analysis of variance. 
- Main components: the repeatability coefficients were estimated using the main components method based on the correlation matrix (CPC) and based on the covariance matrix (CPCV) between each pair of measurements;

- Structural analysis: the repeatability coefficients were estimated based on the correlation matrix (SA) (MANSOUR et al., 1981), whose estimator is the arithmetic mean of the phenotypic correlations among genotypes, considering each pair of measurements.

The number of measurements $\left(\eta_{0}\right)$ needed to predict the true value of the genotypes was obtained by using the repeatability coefficients estimated by the four methods:

$$
\eta_{0}=\frac{\mathrm{R}^{2} \cdot(1-\hat{\mathrm{r}})}{\left(1-\mathrm{R}^{2}\right) \cdot \hat{\mathrm{r}}}
$$

where: $\mathrm{R}^{2}$ represents the genotypic determination coefficient, which is calculated as follows:

$$
\mathrm{R}^{2}=\frac{\eta \cdot r}{1+\mathrm{r} \cdot(\eta-1)}
$$

The Pearson correlation coefficients among all the characters studied were estimated, and their significance was evaluated by the $t$ test, at a $5 \%$ probability level. The Genes program (CRUZ, 2009) was used in all geneticstatistical analyzes.

\section{Results and Discussion}

In general, the fruits presented phenotypic variation for the evaluated characters, with a diameter varying from $8 \mathrm{~cm}$ to $13 \mathrm{~cm}$, length from $14 \mathrm{~cm}$ to $31 \mathrm{~cm}$, fruit weight from $300 \mathrm{~g}$ to $1940 \mathrm{~g}$ and pulp weight from $80 \mathrm{~g}$ to $610 \mathrm{~g}$ (data not shown).

As observed in Table 1, significant differences were found at the $5 \%$ probability level for all characters, evidencing the presence of variability among the studied genotypes. Since there was no replication of genotypes, but rather repetition of fruits within each genotype, the differences observed between them may be due to both genetic and environmental causes (of fruits inside the plant). Fonseca et al. (1990) and Costa et al. (1997) also detected presence of variability among cupuassu trees for a large number of characters studied in Amazonas and Acre. The WSW and PLP characters had the most influence of the environment, with coefficients of variation $(\mathrm{CV})$ of $32.22 \%$ and $45.81 \%$, respectively, while LL and TD were the characters with the lowest coefficients $(12.35 \%$ and $7.40 \%$, respectively). Greater moisture variation among fruits within the same genotype may have been one of the factors that contributed to the higher $\mathrm{CV}$ values obtained for WSW and PLW.

The mean values of the characters LL, TD, TW, PT, PW, PPW, WSW and PLW were $22.36 \mathrm{~cm} ; 105.97$ $\mathrm{mm} ; 943.59 \mathrm{~g} ; 6.72 \mathrm{~mm} ; 384.44 \mathrm{~g} ; 350.79 \mathrm{~g} ; 156.98 \mathrm{~g}$ and $15.82 \mathrm{~g}$, respectively. Although the weight and size of fruits obtained by Costa et al. (1997) and Fonseca et al. (1990) were higher than those obtained here, the pulp yield was similar. According to Calzavara (1987), the average weight of the cupuassu fruit varies from 1000 to $1500 \mathrm{~g}$ and the pulp percentage is around $30 \%$.

Table 2 shows the estimates of the repeatability coefficients (r) obtained by different statistical methods. The estimates of all characters presented variation among the methods, fact that, according to Mansour et al. (1981), can happen when the repeatability coefficients are low. The estimates obtained by ANOVA were lower than those obtained by the other methods. This result was expected, since the genotypic variance estimated by ANOVA is mistaken with the variance of the permanent environment between individuals (COSTA, 2003). The methods based on the main components (CPC and CPCV) were the ones that provided the highest estimates of repeatability.

According to Cruz et al. (2004), the method of structural analysis shows only some conceptual differences from the method of principal components. Thus, the estimates obtained by both tend to be close. For some characters, however, the estimates obtained by the SA method were closer to those obtained by the ANOVA method, what may have occurred due to the fact that the repeatability coefficients were not high.

High repeatability coefficients can be used as parameters to measure the repetition capacity of expression of the evaluated variable (VENCOVSKY, 1973). According to Resende (2002), estimates of the repeatability coefficients are classified as high when they are $\geq 0.6$, averages when they are $<0.6$ and $\geq 0.3$ and low when they are $<0.3$. In the present study, except for the WSW and PLW characters, which presented low repeatability estimates $(0.1428$ to 0.2455$)$, all other characters presented moderate estimates considering the four estimation methods. These results indicate that the studied characters present low to moderate genetic control, and consequently, for the most of the characters there is a certain regularity in the repetition of the same from one fruit to another, within the same genotype. Therefore, the use of more efficient breeding methods, with parental control, should be proposed to obtain expressive genetic gains with the selection. With the exception of WSW and PLW, the estimates of the coefficient of determination $\left(\mathrm{R}^{2}\right)$ were higher than $80 \%$ for all other characters (Table 2), indicating confidence in the prediction of the genotypes real value.

In a study realized by Costa et al. (1997), PT, TW and LL presented repeatability values ranging from 0.7654 to 0.9284 . Fonseca et al. (1990), on the other hand, obtained repeatability coefficients of $0.56 ; 0.46$; $0.58 ; 0.61 ; 0.44$ and 0.56 for, fruit width, LL, PW, PPW, WSW and TW, respectively. The repeatability coefficients obtained by the authors mentioned above were higher 
than those obtained in the present study. However, these authors evaluated a small number of fruits (two to three) per genotype, a fact that may have reduced the accuracy of the repeatability estimates obtained by them.

The number of fruits required $(\eta)$ to perform effective selection of superior genotypes, considering different values of determination coefficient $\left(\mathrm{R}^{2}\right)$, can be observed in Table 3. For all the characters, the number of fruits varied among the methods, and, in general, larger numbers were required by the ANOVA method and smaller numbers by the CPC and CPCV methods. Except for the WSW and PLW characters, which need to evaluate the highest number of fruits to realize the selection of genotypes (21 to 34 for WSW and 17 to 32 for PLW), for the other characters, in general, the evaluation of at least 10 fruits per genotype, considering a coefficient of determination of $85 \%$, is sufficient for an effective selection.

It was estimated that it would be necessary to evaluate at least 11 fruits per genotype with genotypes discrimination at $85 \%$ confidence by the $\mathrm{CPC}, \mathrm{CPCV}$ and SA methods (Table 3). Considering only the methods of the main components, 10 fruits would be sufficient. These values are feasible for cupuassu culture. However, the evaluation of greater number of fruits would imply a greater expense of time and resources for the selection of desirable genotypes, since part of the process needs to be done manually. Costa et al. (1997), considering a coefficient of determination of $80 \%$, found that for TW and pulp yield, 2 and 8 fruits per plant are required, respectively.

Except for the combinations PT $\mathrm{x}$ WSW and PT $\mathrm{x}$ PLW, where phenotypic correlations were not significant, all other phenotypic correlations were significant (Table 4). The character TW presented positive, elevated and significant correlations with LL, TD, PW, PPW and PLW, with values varying from 0.7232 to 0.9291 . High correlations were also obtained between PPW and the characters LL, TD and PLW $(0.7688,0.8312$ and 0.7127 , respectively). Fonseca et al. (1990) also found high correlations between LL and TW (0.752), PW and PPW (0.728), PW and TW (0.901) and PPW and TW (0.912).

The results of correlations indicate the possibility of indirect selection for pulp yield through selection of larger and / or heavy fruits, since high correlation was obtained between these characters and LL and TW presented higher repeatability indexes than the PPW character. In addition, the measurement of LL and TW characters is easier and faster than PPW measurement, since for those the fruit pulping is not necessary.

Table 1.Summary of the analysis of variance for characters evaluated in 10 fruits of 22 genotypes of cupuassu.

\begin{tabular}{lllll}
\hline Characters & MS genotypes & MS residue & Mean & CV (\%) \\
\hline LL $(\mathrm{cm})$ & $61.9540^{*}$ & 7.6229 & 22.36 & 12.35 \\
TD $(\mathrm{mm})$ & $338.5613^{*}$ & 61.5134 & 105.97 & 7.40 \\
TW $(\mathrm{g})$ & $362664.5359^{*}$ & 65470.6136 & 943.59 & 27.12 \\
PT $(\mathrm{mm})$ & $14.5059^{*}$ & 2.7828 & 6.72 & 24.81 \\
SW $(\mathrm{g})$ & $100967.2000^{*}$ & 12515.9840 & 384.44 & 29.10 \\
PPW $(\mathrm{g})$ & $57664.5508^{*}$ & 10468.9733 & 350.79 & 29.17 \\
WSW $(\mathrm{g})$ & $6820.9942^{*}$ & 2558.5499 & 156.98 & 32.22 \\
PLW $(\mathrm{g})$ & $145.9791^{*}$ & 52.5080 & 15.82 & 45.81 \\
\hline
\end{tabular}

${ }^{1}$ Ms: mean square; *: significant at 5\% probability by the F test; CV: coefficient of variation; LL: longitudinal length; TD: transverse diameter; TW: total weight; PT: peel thickness; PW: peel weight; PPW: pulp weight; WSW: wet seed weight; PLW: placental weight. 
Table 2. Estimates of repeatability coefficients $(r)$ and determination coefficients $\left(\mathrm{R}^{2}\right)$ using the variance analysis method (ANOVA), of the main components based on the correlation matrix (CPC), the main components based on the covariance matrix (CPCV) and the structural analysis based on the correlation matrix (SA), for characters evaluated in 10 fruits of 22 cupuassu genotypes.

\begin{tabular}{|c|c|c|c|c|}
\hline \multirow{6}{*}{$\begin{array}{c}\text { Anova } \\
\text { CPC } \\
\text { CPCV } \\
\text { SA }\end{array}$} & $\mathrm{r}$ & $\mathrm{R}^{2}(\%)$ & $r$ & $\mathrm{R}^{2}(\%)$ \\
\hline & \multicolumn{2}{|c|}{ LL } & \multicolumn{2}{|c|}{ TD } \\
\hline & 0.4161 & 87.70 & 0.3105 & 81.83 \\
\hline & 0.4644 & 89.66 & 0.3709 & 85.50 \\
\hline & 0.4563 & 89.35 & 0.3602 & 84.92 \\
\hline & 0.4411 & 88.75 & 0.3421 & 83.87 \\
\hline \multirow{5}{*}{$\begin{array}{c}\text { Anova } \\
\text { CPC } \\
\text { CPCV } \\
\text { SA } \\
\end{array}$} & \multicolumn{2}{|c|}{ TW } & \multicolumn{2}{|c|}{ MPT } \\
\hline & 0.3122 & 81.95 & 0.2964 & 80.82 \\
\hline & 0.4271 & 88.17 & 0.3968 & 86.81 \\
\hline & 0.3812 & 86.03 & 0.3621 & 85.02 \\
\hline & 0.3438 & 83.97 & 0.2981 & 80.94 \\
\hline \multirow{6}{*}{$\begin{array}{c}\text { Anova } \\
\text { CPC } \\
\text { CPCV } \\
\text { SA } \\
\end{array}$} & \multicolumn{2}{|c|}{ PW } & \multicolumn{2}{|c|}{ PPW } \\
\hline & 0.4141 & 87.60 & 0.3107 & 81.84 \\
\hline & 0.5919 & 93.55 & 0.3933 & 86.64 \\
\hline & 0.4925 & 90.66 & 0.3671 & 85.30 \\
\hline & 0.4362 & 88.56 & 0.3517 & 84.44 \\
\hline & \multicolumn{2}{|c|}{ WSW } & \multicolumn{2}{|c|}{ PLW } \\
\hline \multirow{4}{*}{$\begin{array}{c}\text { Anova } \\
\text { CPC } \\
\text { CPCV } \\
\text { SA }\end{array}$} & 0.1428 & 62.49 & 0.1511 & 68.58 \\
\hline & 0.214 & 73.14 & 0.2455 & 76.50 \\
\hline & 0.2012 & 71.58 & 0.2074 & 72.34 \\
\hline & 0.1578 & 65.21 & 0.1803 & 68.75 \\
\hline
\end{tabular}

*LL: longitudinal length; TD: transverse diameter; TW: total weight; PT: peel thickness; PW: peel weight; PPW: pulp weight; WSW: wet seed weight; PLW: placental weight.

Table 3. Number of fruits required $(\eta)$ associated to different determination coefficients $\left(R^{2}\right)$ for characters evaluated in 10 fruits of 22 cupuassu genotypes.

\begin{tabular}{|c|c|c|c|c|c|c|c|c|c|c|c|}
\hline \multicolumn{8}{|c|}{$\eta$} & \multicolumn{4}{|c|}{$\eta$} \\
\hline & $\mathrm{R}^{2}(\%)$ & Anova & $\mathrm{CPC}$ & CPCV & SA & & $\mathrm{R}^{2}(\%)$ & Anova & CPC & $\mathrm{CPCV}$ & SA \\
\hline \multirow[t]{7}{*}{ LL } & 80 & 6 & 5 & 5 & 5 & TD & 80 & 9 & 7 & 7 & 8 \\
\hline & 85 & 8 & 7 & 7 & 7 & & 85 & 13 & 10 & 10 & 11 \\
\hline & 90 & 13 & 10 & 11 & 11 & & 90 & 20 & 15 & 16 & 17 \\
\hline & 95 & 27 & 22 & 23 & 24 & & 95 & 42 & 32 & 34 & 37 \\
\hline & 99 & 138 & 114 & 118 & 125 & & 99 & 220 & 168 & 176 & 190 \\
\hline & \multicolumn{5}{|c|}{$\eta$} & & & \multicolumn{4}{|c|}{$\eta$} \\
\hline & $\mathrm{R}^{2}(\%)$ & Anova & CPC & CPCV & SA & & $\mathrm{R}^{2}(\%)$ & Anova & CPC & $\mathrm{CPCV}$ & SA \\
\hline \multirow[t]{7}{*}{ TW } & 80 & 9 & 5 & 6 & 8 & MPT & 80 & 9 & 6 & 7 & 9 \\
\hline & 85 & 12 & 8 & 9 & 11 & & 85 & 13 & 9 & 10 & 13 \\
\hline & 90 & 17 & 12 & 15 & 17 & & 90 & 21 & 14 & 16 & 21 \\
\hline & 95 & 36 & 25 & 31 & 36 & & 95 & 45 & 29 & 33 & 45 \\
\hline & 99 & 187 & 133 & 161 & 189 & & 99 & 235 & 150 & 174 & 233 \\
\hline & \multicolumn{5}{|c|}{$\eta$} & & & \multicolumn{4}{|c|}{$\eta$} \\
\hline & $\mathrm{R}^{2}(\%)$ & Anova & $\mathrm{CPC}$ & CPCV & SA & & $\mathrm{R}^{2}(\%)$ & Anova & $\mathrm{CPC}$ & CPCV & SA \\
\hline \multirow[t]{7}{*}{$\mathrm{PW}$} & 80 & 6 & 3 & 4 & 5 & PPW & 80 & 9 & 6 & 7 & 7 \\
\hline & 85 & 8 & 4 & 6 & 7 & & 85 & 13 & 9 & 10 & 10 \\
\hline & 90 & 13 & 6 & 9 & 12 & & 90 & 20 & 14 & 16 & 17 \\
\hline & 95 & 27 & 13 & 20 & 25 & & 95 & 42 & 29 & 33 & 35 \\
\hline & 99 & 140 & 68 & 102 & 128 & & 99 & 220 & 153 & 171 & 182 \\
\hline & \multicolumn{5}{|c|}{$\eta$} & & & \multicolumn{4}{|c|}{$\frac{\eta}{n}$} \\
\hline & $\mathrm{R}^{2}(\%)$ & Anova & $\mathrm{CPC}$ & $\mathrm{CPCV}$ & SA & & $\mathrm{R}^{2}(\%)$ & Anova & $\mathrm{CPC}$ & $\mathrm{CPCV}$ & SA \\
\hline WSW & 80 & 24 & 15 & 16 & 21 & PLW & 80 & 22 & 12 & 15 & 18 \\
\hline & 85 & 34 & 21 & 23 & 30 & & 85 & 32 & 17 & 22 & 26 \\
\hline & 90 & 54 & 33 & 36 & 48 & & 90 & 51 & 28 & 34 & 41 \\
\hline & 95 & 114 & 70 & 75 & 101 & & 95 & 107 & 58 & 73 & 86 \\
\hline & 99 & 594 & 364 & 393 & 528 & & 99 & 556 & 304 & 378 & 450 \\
\hline
\end{tabular}

*LL: longitudinal length; TD: transverse diameter; TW: total weight; MPT: mean peel thickness; PW: peel weight; PPW: pulp weight; WSW: wet seed weight; PLW: placental weight. 
Table 4. Phenotypic correlation coefficients among characters evaluated in 10 fruits of 22 cupuassu genotypes.

$\begin{array}{lllllll}\text { TD } & \text { TW } & \text { PT } & \text { PW } & \text { PPW } & \text { WSW } & \text { PLW }\end{array}$

$\begin{array}{lccccccc}\text { LL } & 0.6204 * * & 0.8925^{* *} & 0.5921^{*} & 0.8532^{* *} & 0.7688^{* *} & 0.5470^{* *} & 0.6112^{* *} \\ \text { TD } & & 0.8267 * * & 0.5158^{*} & 0.7055^{* *} & 0.8312^{* *} & 0.5350^{* *} & 0.6016^{* *} \\ \text { TW } & & & 0.6913^{* *} & 0.9291^{* *} & 0.8937^{* *} & 0.6569^{* *} & 0.7232^{* *} \\ \text { PT } & & & 0.8340^{* *} & 0.4324^{*} & 0.3790^{\text {ns }} & 0.3621^{\text {ns }} \\ \text { PW } & & & & & 0.6970^{* *} & 0.5153^{*} & 0.6145^{* *} \\ \text { PPW } & & & & & 0.5290^{*} & 0.7127^{* *} \\ \text { WSW } & & & & & & 0.4400^{*}\end{array}$

** and *: significant at $1 \%$ and $5 \%$ probability by the $t$ test respectively; LL: longitudinal length; TD: transverse diameter; TW: total weight; PT: peel thickness; PW: peel weight; PPW: pulp weight; WSW: wet seed weight; PLW: placental weight.

\section{Conclusion}

The cupuassu genotypes evaluated showed variability for all the studied characters. The estimates of the repeatability coefficients ranged from low to moderate, and, for most characters, overall, 10 fruits are necessary for an effective selection of genotypes, with a coefficient of determination of $85 \%$. The phenotypic selection for larger and / or heavier fruits tends to provide indirect gains for fruits with higher amounts of pulp.

\section{Acknowledgments}

The authors would like to thank the National Research Council - CNPq for the financial support $\left(\mathrm{n}^{\circ}\right.$ 445741/2014-7).

\section{References}

ALVES, R.M. Caracterização genética de populações de cupuaçuzeiro, Theobroma grandiflorum (Willd. ex. Spreng.) Schum., por marcadores microssatélites e descritores botânico-agronômicos. 2003. Tese (Doutorado em Genética e Melhoramento de Plantas) - Escola Superior de Agricultura Luiz de Queiroz, Universidade de São Paulo, Piracicaba, 2003.

CALZAVARA, B.B.G. Cupuaçuzeiro. Belém: Embrapa/ CPATU, 1987. (Recomendações básicas, 1)

COSTA, J.G. Estimativas de repetibilidade de alguns caracteres de produção em mangueira. Ciência Rural, Santa Maria, v.33, n.2, p.263-266, 2003. Disponível em: https://ainfo.cnptia.embrapa.br/digital/bitstream/ item/182365/1/id-26245.pdf. Acesso em: 23 out. 2018.
COSTA, J.G.; LEDO, A.S.; OLIVEIRA, M.N. Estimativas de repetibilidade de características de frutos de cupuaçuzeiro no Estado do Acre. Revista Brasileira de Fruticultura, Jaboticabal, v.19, n.3, p.313-318, 1997. Disponível em: https://ainfo.cnptia.embrapa.br/digital/ bitstream/item/154938/1/1385.pdf. Acesso em: 23 out. 2018.

CRUZ, C.D.; REGAZZI, A.J.; CARNEIRO, P.C.S. Modelos biométricos aplicados ao melhoramento genético. 3.ed. Viçosa: Editora UFV, 2004. v.1. 480p.

CRUZ, C.D. Programa genes: aplicativo computacional em genética e estatística. Versão Windows - 2009.7.0. Viçosa: Editora UFV, 2009.

FONSECA, C.E.L.; ESCOBAR, J.R.; BUENO, D.M. Variabilidade de alguns caracteres físicos e químicos do fruto do cupuaçuzeiro. Pesquisa Agropecuária Brasileira, Brasília, DF, v.25, n.7, p.1079-1084. 1990. Disponível em: https://seer.sct.embrapa.br/index.php/pab/ article/view/13555/7698. Acesso em: 23 out. 2018.

GONDIM, T.M.S.; THOMAZINI, M.J.; CAVALCANTE, M.J.B.; SOUZA, J.M.L. Aspectos da produção de cupuaçu. Rio Branco: Embrapa, 2001. 43p. (Documentos, $67)$.

MANSOUR, H.; NORDHEIM, E.V.; RUTLEDGE, J.J. Estimators of Repeatability. Theoretical and Applied Genetics, Berlin, v.60, n.3, p.151-156, 1981.

RESENDE, M.D.V. de. Genética biométrica e estatística no melhoramento de plantas perenes. Brasília: Embrapa Informação Tecnológica: Colombo: Embrapa Florestas, 2002. $975 p$.

SOUZA, A.G.C.; SOUZA, N.R.; SILVA, S.E.L.; NUNES, C.D.M.; CANTO, A.C.; CRUZ, L.A.A. Fruteiras da Amazônia. Brasília: Embrapa-SPI, 1996. 204p. 
VENCOVSKY, R. Princípios de genética quantitativa. YANG, H.; PROTIVA, P.; CUI, B.; CUIYING, M.A.; 2. ed. Piracicaba: ESALQ, 1973. 97p. (Publicação BAGGETT, S.; HEQUET, V.; MORI, S.; WEINSTEIN, didática, 16). I.B.; KENNELLY, E.J. New bioactive polyphenols from Theobroma grandiflorum ("Cupuaçu”). Journal of Natural Products, Ohio, v. 66, n.11, p.1501-1504, 2003. 